\title{
Fluidized Bed Coating Method
}

National Cancer Institute

\section{Source}

National Cancer Institute. Fluidized Bed Coating Method. NCI Thesaurus. Code C112971.

A method that suspends a substrate in a fluidized bed while it is sprayed with a layer of coating material. 